\title{
Perbedaan Lama Waktu Kembali Hamil pada KB Suntik 1 Bulan dengan KB Suntik 3 Bulan di Wilayah Kerja Puskesmas Daya Murni Kabupaten Tulang Bawang Barat Lampung
}

\author{
Ari Julisa Harni ${ }^{1}$, Anita ${ }^{2}$ \\ ${ }^{1}$ Jurusan Keperawatan, STIKES Mitra Lampung \\ ${ }^{2}$ Jurusan Keperawatan, Politeknik Kesehatan Tanjungkarang \\ Email: arijulisaharni@gmail.com
}

\begin{abstract}
The Difference Of The Length Of Re-Pregnant Towards The Use Of 1 Month Contraception Injection With 3 Months Contraception Injection In The Working Area Of Puskesmas Daya Murni, Tulang Bawang Barat Lampung. A long time to get pregnant is the lag time of the return of pregnancy after the discontinuation of contraceptive use or after the end of the previous pregnancy. One of the factors that affect the time of return of pregnancy is the use of contraception. According to WHO the time to return pregnant normally is less than 6 months. The purpose of this study was to determine the difference in the duration of re-pregnancy in the mother of 1 month injection acceptor KB with 3 month injection in the work area of Puskesmas Daya Murni Tumijajar District, Regency Year 2017. This type of research is quantitative research. The population in this study were all women hormonal contraceptive mother ( 1 month injection and 3 month injection) who had been pregnant or have given birth and are currently pregnant with 126 acceptors. The number of samples in this study was 96 respondents. The result of statistic test in obtaining p-value 0.000 which mean at significance value $\leq 0,05$ can be concluded there is a difference of mean time duration of pregnancy return between 1 month injection and 3 month injection. Researchers suggest to further researchers to be able to conduct research and studies of other factors that affect the length of time re-pregnant.
\end{abstract}

Keywords: Contraception, Hormonal Contraceptive Mother, Long Time Back Pregnant

\begin{abstract}
Abstrak: Perbedaan Lama Waktu Kembali Hamil pada KB Suntik 1 Bulan dengan KB Suntik 3 Bulan di Wilayah Kerja Puskesmas Daya Murni, Kabupaten Tulang Bawang Barat Lampung. Waktu lama kembali hamil adalah jeda waktu kembalinya kehamilan setelah dihentikannya penggunaan kontrasepsi ataupun setelah berakhirnya kehamilan sebelumnya. Salah satu faktor yang berpengaruh terhadap waktu kembalinya kehamilan adalah penggunaan kontrasepsi. Menurut WHO waktu kembali hamil secara normalnya adalah kurang dari 6 bulan. Tujuan penelitian ini adalah untuk mengetahui perbedaan lama waktu kembali hamil pada ibu akseptor KB suntik 1 bulan dengan KB suntik 3 bulan di wilayah kerja Puskesmas Daya Murni Kecamatan Tumijajar Kabupaten Tulang Bawang Barat Tahun 2017. Jenis penelitian ini adalah penelitian kuantitatif. Populasi dalam penelitian ini adalah semua ibu akseptor KB hormonal (KB suntik 1 bulan dan KB suntik 3 bulan) yang sudah pernah hamil atau melahirkan dan saat ini hamil sejumlah 126 akseptor. Jumlah sampel dalam penelitian ini sebanyak 96 responden. Hasil uji statistik di dapatkan p-value 0.000 yang berarti pada nilai signifikansi $₫ 0.05$ dapat disimpulkan terdapat perbedaan rata-rata waktu lama kembali hamil antara KB suntik 1 bulan dan KB suntik 3 bulan. Peneliti menyarankan kepada peneliti selanjutnya untuk dapat melakukan penelitian dan kajian tentang faktor-faktor lain yang berpengaruh terhadap lamanya waktu kembali hamil.
\end{abstract}

Kata kunci: Kontrasepsi, Ibu Akseptor KB, Lama Waktu Kembali Hamil

Kontrasepsi merupakan salah satu upaya untuk mencegah terjadinya kehamilan. Upaya itu dapat bersifat sementara, dapat pula bersifat permanen. Pada saat ini telah banyak beredar berbagai macam alat kontrasepsi. Macam-macam metode kontrasepsi tersebut adalah Intra Uterine Device, implant, kondom, suntik ,metode operatif untuk wanita (MOW), metode operatif untuk pria (MOP), dan kontrasepsi pil. Alat kontrasepsi hendaknya memenuhi syarat yaitu aman pemakaiannya dan dapat dipercaya, efek samping yang merugikan tidak ada, lama kerjanya dapat diatur keinginan, tidak mengganggu hubungan seksual, harganya murah dan dapat diterima oleh pasangan suami istri (BKKBN, 2006).

Tujuan dari kontrasepsi dapat diklasifikasikan dalam tiga kategori yaitu menunda kehamilan atau mencegah kehamilan, 
menjarangkan kehamilan serta menghentikan atau mengakhiri kehamilan atau kesuburan (Everett, 2007).

Waktu lama kembali hamil adalah jeda waktu kembalinya kehamilan setelah dihentikannya penggunaan kontrasepsi ataupun setelah berakhirnya kehamilan sebelumnya. Waktu kembalinya kehamilan seringkali dikeluhkan oleh pasangan usia subur yang menginginkan terjadinya kehamilan dengan cepat, namun terdapat beberapa faktor yang dapat menyebabkan waktu kembali hamil terjadi cukup lama (Varney, 2010).

Menurut WHO normalnya waktu kembali hamil secara normalnya adalah kurang dari 6 bulan, namun berdasarkan hasil penelitian yang dilakukan oleh WHO di wilayah eropa dan amerika selatan diketahui bahwa rata-rata waktu kembali hamil pada wanita subur yaitu sekitar 68 bulan, dan masih terdapat sekitar 30\% wanita yang mengalami waktu kembali hamil lebih dari 6 bulan. Sedangkan di daerah Asia khususnya di daerah berkembang seperti Vietnam dan India rata-rata lama waktu kembali hamil yaitu antara 4-12 bulan dan masih terdapat sekitar 53.5\% wanita yang mengalami waktu lama kembali hamil lebih dari 6 Bulan (Fahira, 2014).

Pada penggunaan kontrasepsi hormonal khususnya suntik 3 bulan yang cukup lama akan mempengaruhi proses pengembalian keseimbangan hormonal dan menyebabkan proses kehamilan akan berjalan lambat untuk beberapa waktu, meskipun telah berhenti menggunakan kontrasepsi tersebut. Hal tersebut dikarenakan penggunaan DMPA akan mengakibatkan pembentukan LHRF (Lutuinizing Hormon Relacing Faktor) dan FSHRF (Folicle Stimulating Hormone Relasing) yang dapat mengubah lendir serviks menjadi kental, dan tidak dapat berhenti dengan cepat dikarenakan kembalinya perubahan hormon akan lebih lambat jika dibandingkan KB 1 bulan atau KB kombinasi (Fahira, 2014).

Hasil pra survey di Puskesmas Daya Murni didapatkan penggunaan jenis kontrasepsi terbanyak digunakan adalah KB suntik 3 bulan yaitu sebanyak 84 (46.9\%) dan kontrasepsi suntik 1 bulan sebanyak 42 (23.4\%), KB implant sebanyak 24 (13.4\%), dan KB IUD sebanyak 13 (7.2\%) dan tidak KB sebanyak $16(8.9 \%)$ dari total 179 PUS (Pasangan usia subur) (Data puskesmas Daya Murni bulan januari-mei 2017). Sedangkan untuk hasil survey kembali hamil yang di lakukan di puskesmas Daya Murni Kecamatan Tumijajar pada tahun 2016 terdapat sekitar 30 wanita yang memeriksakan diri kepuskesmas dikarenakan tidak segera mengalami kehamilan setelah berhenti menggunakan kontrasepsi selama 6 bulan. Berdasarkan hasil wawancara yang peneliti lakukan pada $10 \mathrm{ibu}$ akseptor KB diketahui bahwa terdapat $7(70 \%)$ ibu yang mengalami waktu lama kembali hamil lebih dari 6 bulan dan $3(30 \%)$ ibu yang mengalami waktu lama kembali hamil kurang dari 6 bulan.

Penelitian ini bertujuan untuk mengetahui perbedaan lama waktu kembali hamil pada ibu akseptor kb suntik 1 bulan dengan KB suntik 3 bulan di wilayah kerja puskesmas Daya Murni Kecamatan Tumijajar Kabupaten Tulang Bawang Barat Tahun 2017.

\section{METODE}

Penelitian ini merupakan jenis penelitian kuantitatif. Desain penelitian yang dipakai dalam penelitian ini adalah desain analitik korelatif dengan pendekatan cross sectional.

Populasi penelitian adalah semua ibu akseptor KB hormonal (KB suntik 1 bulan dan $\mathrm{KB}$ suntik 3 bulan) yang sudah pernah hamil, sudah pernah melahirkan dan saat ini hamildi Wilayah Kerja Puskesmas Daya Murni Kecamatan Tumijajar Kabupaten Tulang Bawang Barat Tahun 2017 sejumlah 126 akseptor. Dan sampel dalam penelitian ini berjumlah 96 orang.

Pengumpulan data yang dilakukan oleh peneliti yaitu dengan cara mengumpulkan data langsung dari objek penelitian, menggunakan alat ukur kuisioner. Peneliti langsung mendatangi responden serta menanyakan beberapa hal pertanyaan setelah memperkenalkan diri seraya meminta kesediaan untuk menjadi responden dengan memaparkan maksud dan tujuan dari memberikan pertanyaan, ini dilakukan untuk menciptakan rasa nyaman dan aman bagi responden. Setelah itu peneliti menayakan pertanyaan-pertanyaan yang ada di kuisioner kepada responden dan tidak membatasi waktu untuk responden berfikir tentang jawaban dari pertanyaan yang peneliti ajukan.

Analisa dalam penelitian ini dilakukan secara analisa univariat dan analisa bivariat. Analisa univariat dilakukan untuk melihat distribusi frekuensi variabel dependen dan variabel independent. Data yang terkumpul dalam penelitian ini akan diolah dengan menggunakan komputer.

Analisa bivariat adalah analisa yang digunakan untuk mengetahui keterkaitan antara variabel bebas dan variabel terikat dengan menggunakan uji statistik. Uji statistik yang digunakan dalam penelitian ini adalah uji $T$ 
(Independent samples T-Test) dengan nilai signifikansi $₫ 0.05$.

\section{HASIL}

\section{A. ANALISIS UNIVARIAT}

\section{Tabel 1. Distribusi Frekuensi Penggunaan} Kontrasepsi Hormonal

\begin{tabular}{crr}
\hline KB Hormonal & Jumlah & \% \\
\hline KB Suntik 1 Bulan & 42 & 43.8 \\
\hline KB Suntik 3 Bulan & 54 & 56.2 \\
\hline Total & 96 & 100.0 \\
\hline
\end{tabular}

Berdasarkan tabel 1 diketahui bahwa lebih banyak responden yang menggunakan KB suntik 3 bulan yaitu sebanyak $54 \quad(56.2 \%)$ jika dibandingkan $\mathrm{KB}$ suntik 1 bulan yaitu sebanyak $42(43.8 \%)$.

Tabel 2. Rata-rata Waktu Kembali Hamil pada Ibu Akseptor KB

\begin{tabular}{lcccc}
\hline & $\begin{array}{c}\text { Mean } \\
\text { Med }\end{array}$ & SD & $\begin{array}{c}\text { Min } \\
\text { Maks }\end{array}$ & $\begin{array}{c}\text { 95 \% } \\
\text { CI }\end{array}$ \\
\hline Rata-rata waktu & 6.66 & 2.9 & 2 & $6.06-$ \\
kembali hamil & 7.00 & & 12 & 7.25 \\
\hline
\end{tabular}

Berdasarkan tabel 2 diketahui bahwa ratarata waktu kembali hamil pada responden penelitian yaitu 6.66 bulan (95\% CI 6.06-7.25) median 7.00 dengan standard deviasi 2.9, waktu tercepat kembali hamil adalah 2 bulan dan waktu kembali hamil terlama adalah 12 bulan Berdasarkan tabel diatas diyakini bahwa rata-rata waktu kembali hamil pada responden yaitu antara 6.06 bulan sampai 7.25 bulan.

\section{B. ANALISIS BIVARIAT}

Tabel 3. Perbandingan antara Lama Waktu Kembali Hamil pada Ibu Akseptor KB Suntik 1 Bulan dengan KB Suntik 3 Bulan

\begin{tabular}{cccccc}
\hline Variabel & Mean & SD & SE & $\begin{array}{c}\boldsymbol{p} \text { - } \\
\text { value }\end{array}$ & n \\
\hline KB suntik 1 bulan & 4.12 & 1.8 & 0.2 & 0.000 & 96 \\
\hline KB suntik 3 bulan & 8.63 & 2.0 & 0.2 & & \\
\hline
\end{tabular}

Berdasarkan tabel 3 diketahui bahwa ratarata waktu kembali hamil pada responden yang menggunakan KB suntik 1 bulan lebih cepat dari pada responden yang menggunakan $\mathrm{KB}$ suntik 3 bulan dengan rata-rata waktu kembali hamil pada $\mathrm{KB}$ suntik 1 bulan yaitu 4.12 bulan dengan standard eror (SE) 0.3, Sedangkan pada KB 3 bulan rata-rata waktu kembali hamil yaitu 8.63 bulan dengan standard error (SE) 0.3 yang berarti terdapat perbedaan rata-rata waktu kembali hamil antara akseptor KB 1 bulan dan akseptor KB 3 bulan. Hasil uji statistik di daptkan $p$-value 0.000 yang berarti pada nilai signifikansi $\$ 0.05$ dapat disimpulkan terdapat perbedaan ratarata waktu lama kembali hamil antara KB suntik 1 bulan dan KB suntik 3 bulan

\section{PEMBAHASAN}

Berdasarkan hasil penelitian diketahui bahwa lebih banyak responden yang menggunakan $\mathrm{KB}$ suntik 3 bulan yaitu sebanyak $54(56.3 .8 \%)$ jika dibandingkan KB suntik 1 bulan yaitu sebanyak 42 (43.8\%). Sedangkan diketahui bahwa rata-rata waktu kembali hamil pada responden yang menggunakan KB suntik 1 bulan lebih cepat dari pada responden yang menggunakan KB suntik 3 bulan dengan rata-rata waktu kembali hamil pada KB suntik 1 bulan yaitu 4.12 bulan, dan standard error (SE) 0.3 yang berarti terdapat perbedaan rata-rata waktu kembali hamil pada penggunaan $\mathrm{KB}$ suntik 1 bulan dan KB suntik 3 bulan.

Hasil uji statistik didapatkan $p$-value 0.000 yang berarti pada nilai signifikansi $₫ 0.05$ dapat disimpulkan ada perbandingan antara $\mathrm{KB}$ suntik 1 bulan dan KB suntik 3 bulan. Pada penggunaan kontrasepsi hormonal khususnya suntik 3 bulan yang cukup lama akan mempengaruhi proses pengembalian keseimbangan hormonal dan menyebabkan proses kehamilan akan berjalan lambat untuk beberapa waktu, meskipun telah berhenti menggunakan kontrasepsi tersebut. Hal tersebut dikarenakan penggunaan DMPA akan mengakibatkan pembentukan LHRF (Lutuinizing HormonRelacing Faktor) dan FSHRF (Folicle Stimulating Hormone Relasing) yang dapat mengubah lendir serviks menjadi kental, dan tidak dapat berhenti dengan cepat dikarenakan kembalinya perubahan hormon akan lebih lambat jika dibandingkan KB 1 bulan atau KB kombinasi (Fahira, 2014).

Hasil penelitian ini sejalan dengan penelitian Agustin (2017) bahwa rata-rata pengembalian kesuburan pasca $\mathrm{KB}$ suntik 1 bulan adalah 7,1 bulan, dan pengembalian kesuburan pasca KB suntik 3 bulan adalah 13,9 bulan. Nilai $\mathrm{t}$ hitung $=-3,874$ dengan $\mathrm{p}$-value sebesar 0,001, dimana ada perbedaan yang signifikan antara pengembalian kesuburan pada ibu pasca KB suntik 1 bulan dan 3 bulan (DMPA) di desa Nyatnyono Kecamatan Ungaran Barat Kabupaten Semarang.

Penggunaan KB akan berpengaruh terhadap proses terjadinya kehamilan, terutama pada penggunaan KB hormonal, akan terjadi efek 
komulatif yang dapat menyebabkan waktu kembalinya kehamilan cukup lama. Pada penggunaan $\mathrm{KB}$ hormonal menggunkan DMPA (Depot medroksi progesterone) akan menimbulkan efek komulatif yang lebih banyak di bandingkan dengan KB hormonal kombinasi seperti suntik KB 1 bulan.

Pada KB Hormonal 3 bulan menggunakan hormon progesteron akan dapat mempengaruhi terjadinya ovulasi melalui mekanisme jika ovum yang telah matang tidak dibuahi oeh sperma. Konsentrasi progesteron menyebabkan gangguan terhadap proses pembuahan. Dengan demikian progesteron tidak lagi mampu memelihara jaringan endometrium di dalam rahim. Oleh karena tidak terjadi pembuahan maka jaringan ini tidak dibutuhkan. Jaringan ini akan lebih mudah dihancurkan oleh sel darah putih karena kadar progesteron yang rendah, dan akan dikeluarkan bersama ovum yang tidak dibuahi, proses ini dikenal dengan menstruasi, yakni meluruhnya dinding rahim bersama ovum yang berakibat pada tidak terjadinya proses kehamilan.

Salah satu efek samping dari penggunaan $\mathrm{KB}$ suntik 3 bulan atau DMPA yang merupakan metode KB paling banyak digunakan adalah kembalinya siklus menstruasi dan kesuburan yang lambat. Kembalinya kesuburan yang ditandai dengan teraturnya siklus menstruasi setelah berhenti KB. Kesuburan tidak akan langsung kembali setelah penghentian KB suntik. Pada pemakaian KB suntik khusunya KB suntik 3 bulan siklus menstruasi akan kembali terjadi dalam waktu 6 bulan-1 tahun setelah pemakaian suntikan $\mathrm{KB}$ dihentikan begitu juga dengan keseburuan ibu, berbeda dengan injeksi KB kombinasi atau suntik 1 bulan siklus menstruasi akan dapat kembali lebih cepat yakni sekitar 2-6 bulan (Nur'aini, 2014).

Kembalinya kesuburan yang ditandai dengan teraturnya siklus menstruasi setelah berhenti KB suntik memang memerlukan waktu yang bervariasi. Kesuburan tidak akan langsung kembali setelah penghentian KB suntik. Hal ini tergantung pada kecepatan metabolisme DMPA dan juga pada berat badan akseptor KB suntik. Lebih dari 50\% mantan akseptor akan mengalami haid kembali setelah 6-12 bulan dan rata-rata $85 \% 12$ bulan dari suntik yang terakhir. Lama atau tidaknya penggunaan kontrasepsi suntik 3 bulan menyebabkan terjadinya efek komulatif dari obatnya lebih banyak dari pada suntik 1 bulan, hal tersebut yang menyebabkan kembalinya kehamilan pada KB 1 bulan lebih cepat (Hartanto, 2004).

Obat KB khususnya DMPA yang disuntikan akan tersimpan dalam jaringan lemak tubuh sehingga dalam darahnya masih tersimpan hormon progesteron, maka sebagian wanita memerlukan waktu untuk mendapatkan kesuburan rahim yang sebelumnya kondisi pada dinding endometrium mengalami atrofi dengan kelenjar yang tidak aktif. Penumpukan hormon secara komulatif akan terjadi lebih banyak pada KB suntik 3 bulan dari pada KB suntik 1 bulan (Hartanto, 2004).

Proses kehamilan dimulai dari proses ovulasi, konsepsi, hingga implantasi dalam rahim. Ovulasi terjadi ketika sel telur (ovum) keluar dari sarangnya (ovarium=indung telur). Ovulasi ini normalnya terjadi setiap bulan sesuai siklus menstruasi dan rata-rata terjadi sekitar dua minggu sebelum periode (siklus) mens berikutnya. Kenaikan Hormon Setelah telur meninggalkan folikel, folikel berkembang menjadi sesuatu yang disebut korpus luteum. Korpus luteum melepaskan hormon yang membantu menebalkan lapisan rahim, untuk mempersiapkan ketika terjadi proses kehamilan nantinya. Telur Berjalan ke Tuba Fallopi Setelah telur dilepaskan, dan bergerak ke tuba falopi. Sel telur tinggal di sana selama sekitar 24 jam, menunggu sel sperma untuk membuahi. Semua ini terjadi, rata-rata, sekitar dua minggu setelah hari pertama menstruasi terakhir atau masa ini disebut juga dengan masa subur Penggunaan KB DMPA menyebabkan akumulasi. Kadar hormon progesteron sehingga lapisan rahim yang menebal tadi menjadi luruh, dan terjadi lagi menstruasi atau haid. Dan terkadang pada penggunaan kontrasepsi hormonal ini meskipun tidak mengalami kehamilan tetapi tidak terjadi menstruasi hal tersebut dikarenakan kesuburan pada wanita yang mengalami gangguan akibat proses akumulasi hormon (Prawiroharjo, 2008).

Hasil penelitian yang dilakukan oleh peneliti diatas serta teori diatas didukung juga dengan adanya penelitian yang dilakukan oleh Handayani (2010) dengan judul Hubungan Lamanya Pemakaian Kontrasepsi Suntik DMPA dengan Kembalinya Kesuburan Pada Post Akseptor KB Suntik DMPA. Lama penggunaan KB suntik DMPA pada wanita ex-akseptor KB suntik DMPA di wilayah Kota Administratif Purwokertorata-rata adalah 25,39 Bulan sedangkan lama kembalinya kesuburan pada wanita ex-akseptor KB suntik DMPA rata-rata adalah 8,82 Bulan. Terdapat hubungan antara lamanya penggunaan KB suntik DMPA dengan lama kembalinya kesuburan pada wanita exakseptor KB suntik DMPA dengan $\rho$ value $=0,019$.

Hasil penelitian yang sama juga di dapatkan pada penelitian yang dilakukan oleh 
Izza (2014) dengan judul Perbedaan Waktu Terjadinya Kehamilan Pada Ibu Pasca Menggunakan KB Suntik 1 dan 3 Bulan Di Puskesmas Bangsal Mojokerto. Hasil penelitian menunjukkan bahwa rentan waktu ibu hamil setelah menggunakan KB suntik 1 bulan $<3$ bulan sejumlah 13 responden $(44,8 \%)$. Sedangkan, rentan waktu ibu hamil setelah menggunakan KB suntik 3 bulan adalah $>5$ bulan sejumlah 14 responden $(48,3 \%)$. Berdasarkan hasil penelitian didapatkan setelah penghentian penggunaan kontrasepsi lain yaitu rata-rata 2 bulan, sedangkan setelah penghentian penggunaan suntik DMPA 1 bulan dan 3 bulan memerlukan waktu rata-rata 4 sampai 10 bulan.

Berdasarkan hasil penelitian dan uji statistik yang telah peneliti lakukan, teori dan penelitian terdahulu yang menguatkan tentang mekanisme kembalinya hamil pada akseptor KB hormonal (suntik 1 bulan dan suntik 3 bulan) maka peneliti dapat menyimpulkan bahwa dalam penelitian ini terdapat perbedaan waktu kembali hamil pada ibu akseptor KB suntik 1 bulan dengan KB suntik 3 bulan diwilayah kerja puskesmas Daya Murni kecamatan Tumijajar kabupatan Tulang Bawang Barat tahun 2017.

\section{SIMPULAN}

Dapat diketahui bahwa responden yang menggunakan KB suntik 3 bulan yaitu sebanyak $32(57.1 \%)$ jika dibandingkan KB suntik 1 bulan yaitu sebanyak 24 (42.9\%). Sedangkan rata-rata waktu kembali hamilnya yaitu 6.70 bulan. Sehingga dari hasil penelitian di dapatkan Ada perbedaan lama waktu kembali hamil pada ibu

\section{DAFTAR PUSTAKA}

Agustin, R., \& Waluyo, A. K. N. 2017. Perbedaan Pengembalian Kesuburan Pasca KB Suntik 1 Bulan dan KB Suntik 3 bulan (DMPA) di Desa Nyatnyono Kecamatan Ungaran Barat Kabupaten Semarang. Karya Tulis Ilmiah, Akademi Kebidanan Ngudi Waluyo Ungaran.

BKKBN. 2006. Konversi Peserta Keluarga Berencana menurut Jenis Kontrasepsi http://www.bkkbn.go.id. (Diakses pada tanggal 20 Maret 2015).

Evveret. 2007. Keluarga Berencana \& Kesehatan Reproduksi. Jakarta: EGC.

Fahira. 2014. Faktor-faktor yang Berhubungan dengan Kebutuhan Keluarga Berencana yang Tidak Terpenuhi (Unmet Need) di akseptor kb suntik 1 bulan dengan kb suntik 3 bulan di wilayah kerja puskesmas Daya Murni Kecamatan Tumijajar Kabupaten Tulang Bawang Barat Tahun 2017, dibuktikan dengan hasil uji statistik yang didapatkan yaitu p-value 0.000 .

\section{SARAN}

1. Untuk Puskesmas

Peneliti menyarankan kepada puskesmas untuk dapat melakukan sosialisasi tentang efek samping penggunaan $\mathrm{KB}$ hormonal serta konseling dalam menentukan jenis KB pada masyarakat guna mendapatkan metode $\mathrm{KB}$ yang sesuai dengan kebutuhan akseptor KB.

2. Untuk Tenaga Kesehatan

Peneliti menyarankan kepada tenaga kesehatan untuk memberikan edukasi pada akseptor KB atau masyarakat untuk menggunkan $\mathrm{KB}$ suntik 1 bulan jika ingin cepat hamil kembali setelah berhenti KB, namun jika tidak menginginkan hamil kembali maka disarankan untuk menggunakan KB suntik 3 bulan.

3. Untuk Penangung Jawab Program

Peneliti menyarankan untuk penanggung jawab program selalu melakukan evaluasi terhadap efek samping pada penggunaan $\mathrm{KB}$ yang dikeluhkan oleh akseptor KB.

4. Untuk Peneliti Selanjutnya

Peneliti menyarankan kepada peneliti selanjutya untuk dapat melakukan penelitian dan kajian tentang faktor-faktor lain yang berpengaruh terhadap lamanya waktu kembali hamil.

Kecamatan Sipatana Kota Gorontalo. Tesis, Fakultas Kedokteran, Universitas Indonesia. Handayani, R., Fajarsari, D., \& Suryani, E. S. 2010. Hubungan Lamanya Pemakaian Kontrasepsi Suntik DMPA Dengan Kembalinya Kesuburan Pada Post Akseptor KB Suntik DMPA. Jurnal Bidan Prada, 1 (01).

Hastono, Sutanto Priyo. 2007. Analisa Data

Kesehatan. Jakarta: Fakultas Ilmu Kesehatan Masyarakat UI.

Hartanto, H. 2004. Keluarga Berencana dan Kontrasepsi. Jakarta: Pustaka Sinar Harapan.

Izza. 2014. Perbedaan Waktu terjadinya Kehamilan pada Ibu Pasca Menggunakan KB Suntik 1 dan 3 Bulan di Puskesmas Bangsal 
Mojokerto. KTI D3 Kebidanan, Poltekkes Majapahit Mojokerto.

Nura'ini. 2014. Pengantar KB dan Penyakit Kandungan. Jakarta: Salemba Medika.
Prawirohardjo. 2008. Ilmu Kandungan. Jakarta: Yayasan Bina Pustaka Sarwono Prawirohardjo.

Varney, Hellen. 2010. Buku Saku Bidan. Jakarta: EGC. 